bioRxiv preprint doi: https://doi.org/10.1101/2021 05.07 443137· this version posted May 8, 2021. The copyright holder for this preprint (which was not certified by peer review) is the author/funder, who has granted bioRxiv a license to display the preprint in perpetuity. It is made available under aCC-BY 4.0 International license.

\title{
1 SwrA as global modulator of the two-component system DegS/U in B. subtilis
}

2 Francesca Ermoli, Giulia Vitali, Cinzia Calvio*

3 Laboratories of Genetics and Microbiology, Dept. of Biology and Biotechnology, University of Pavia (I).

$4 \quad$ *corresponding author: cinzia.calvio@unipv.it 
The two-component system DegS/U of Bacillus subtilis controls more than one hundred genes involved

9 in several different cellular behaviours. Since the consensus sequence recognized by the response regulator

10 DegU has not been clearly defined yet, mutations in either component have been crucial in the

11 identification of the cellular targets of this regulatory system. Over the years, the degU $32^{\mathrm{Hy}}$ mutant allele, that was supposed to mimic the activated regulator, has been commonly used to define the impact of this TCS on its regulated genes in domestic strains.

SwrA encodes a small protein essential for swarming motility and for poly- - -glutamate biosynthesis and is only present in wild strains. Previous work indicated that SwrA is partnering with DegU P in exerting its role on both phenotypes.

In this work, inserting a degS $200^{\mathrm{Hy}}$ mutation in $s w r A^{+}$and $s w r A^{-}$isogenic strains we demonstrate that SwrA modulates the action of DegU P on two new phenotypes, subtilisin expression and competence for DNA uptake, with a remarkable effect on transformation. These effects cannot not be appreciated with the 
bioRxiv preprint doi: https://doi org/10.1101/2021.05.07.443137; this version posted May 8,2021 . The copyright holder for this preprint (which was not certified by peer review) is the author/funder, who has granted bioRxiv a license to display the preprint in perpetuity. It is made available under aCC-BY 4.0 International license.

\section{INTRODUCTION}

Two-component systems (TCS) are signal transduction modules common in bacteria and archaea, composed by a sensor histidine kinase and a cognate response regulator. Sensor kinases autophosphorylate themselves on a histidine residue in response to specific environmental signals and then transfer the phosphate group to a specific aspartic acid residue of the regulator inducing a structural rearrangement that enables it to modify its DNA binding properties and regulate gene expression. Moreover, sensor kinases can often quench spurious signals by dephosphorylating their cognate regulators (1). The DegS/U TCS, composed by the cytoplasmic DegS kinase and the DegU transcription factor, is involved in the regulation of several important physiological pathways of Bacillus subtilis, among which flagella-mediated motility, degradative enzyme synthesis, genetic competence, and sporulation (2). The extremely wide impact of this TCS has been evidenced through several transcriptional profiling experiments (3-5). A particular class of mutations in either DegS or DegU leads to the hyperproduction of several degradative enzymes, including the aprE-encoded protease subtilisin, and has therefore been named "Hy" (6-8). Besides promoting the synthesis of several degradative enzymes, the pleiotropic Hy mutations also cause the so called Hy phenotype which includes loss of DNA competence, absence of flagella, sporulation in the presence of glucose and elongated cell morphology $(6,9,10)$. A Hy phenotype is also observed when two small proteins, DegQ and DegR, are overexpressed. They are both involved in the DegS/U signalling pathway: DegQ stimulates the transfer of the phosphate moiety from DegS to DegU (5), while DegR stabilizes DegU P by preventing DegS-mediated DegU P dephosphorylation (11). The overexpression of DegQ naturally occurs in wild $B$. subtilis strains, thanks to a nucleotide change in the -10 box of its promoter that leads to 10 -fold increase in transcription with respect to domestic strains $(12,13)$; however, the $\operatorname{deg} \mathrm{Q}^{\mathrm{Hy}}$ mutation present in undomesticated strains only generates a mild phenotype, as these strains,

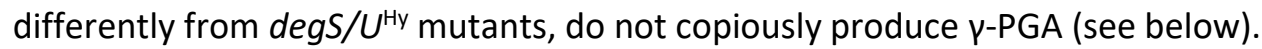

Among the number of originally isolated Hy mutants (6), subsequent studies have heavily relayed on $\operatorname{deg} U 32^{\mathrm{Hy}}$, a particular degU allele which carries an A-to-T transversion at nucleotide 35 of the degU ORF, leading to a His to Leu amino acid change at position 12 (14). In early studies, all DegU32 $2^{\text {Hy }}$ phenotypes matched those obtained with the DegS200 ${ }^{\mathrm{Hy}}$ mutant, in which the Gly to Glu mutation at position 218 of DegS impairs the phosphatase activity of the sensor kinase, thus leading to the accumulation of DegU P (15). From the perfectly overlapping phenotypes of the two mutants, DegU32 $2^{\text {Hy }}$ has been since considered as a constitutively active proxy of DegU $\sim \mathrm{P}$, without any further structural characterization. Only recently such interpretation has been challenged, thanks to the introduction of a new player, SwrA (16).

SwrA is also a small protein, 117 aa, which has been discovered thanks to its fundamental role in swarming motility (17). Its existence remained long undisclosed due to the fact that domestic $B$. subtilis strains only encode a non-functional 13 aa truncated peptide because of the insertion of an extra adenine 
bioRxiv preprint doi: https://doi org/10.1101/2021.05.07.443137: this version posted May 8.2021 . The copyriaht holder for this preprint (which was not certified by peer review) is the author/funder, who has granted bioRxiv a license to display the preprint in perpetuity. It is made available under aCC-BY 4.0 International license.

in a poly-A tract in swrA ORF causing a frameshift mutation (17-19). This type of mutations can easily flip back to the wild-type form (wt) and vice versa with the frequency of a phase-variation event (17). It is thus frequent to obtain mixed $s w r A^{+/-}$populations even in laboratory strains upon prolonged incubations. When functional, SwrA stimulates flagella production through its activity at the $\mathrm{P}_{\mathrm{fla} / \mathrm{che}}$ promoter, thereby promoting sigD transcription which also permits efficient cell septation $(16,19-21)$. Although initially confined to motility regulation, the role of SwrA was also shown to be essential for the expression of the otherwise-silent pgs operon, encoding the enzymes required for the synthesis of the biopolymer poly- $\gamma^{-}$ glutamic acid ( $\gamma$-PGA) (22). Interestingly, $\gamma$-PGA production not only strictly depends on SwrA but also on a Hy mutation in either DegQ (23) or DegU/S (24). This was the first evidence of a strict connection between SwrA and the DegS/U TCS.

Further genetic evidence of the link between SwrA and the DegS/U was gained by studies on the fla/che operon, in which the direct interaction between DegU P and SwrA was demonstrated genetically and biochemically. Genetically, it was observed that while degU32 ${ }^{\mathrm{Hy}}$ and degS200 ${ }^{\mathrm{Hy}}$ mutants completely suppress $\mathrm{P}_{\mathrm{fla}}$ /che expression in laboratory strain lacking SwrA, leading to the classically non-flagellated Hyphenotype $(6,10)$, the restoration of a functional swrA allele leads to hyperflagellation in $\operatorname{deg} S 200^{\mathrm{Hy}}$ mutants as well as in degS/ $\mathrm{U}^{\text {wt }}$ backgrounds, although not in degUS32 $2^{\mathrm{Hy}}$ mutants (16). Biochemically, it was shown that, in electro mobility shift assays, the DegU P-bound fla/che promoter is super-shifted in the presence of SwrA while DegU32 ${ }^{\mathrm{Hy}}$ is not; moreover, DegU32 ${ }^{\mathrm{Hy}}$ does not require phosphorylation for DNA binding (16). The physical interaction between DegU and SwrA was also evidenced in other studies (25). Ultimately, the impact of SwrA on motility is to remarkably turn the $\mathrm{P}_{\mathrm{fla} / \mathrm{che}}$ repressive effect of DegU P, naturally produced or induced by a degS200 ${ }^{\mathrm{Hy}}$ mutation, into a transcriptional boost, thus allowing swarming motility $(16,21)$. This dramatic overturn of DegU P impact on the motility operon could not be appreciated in domestic strains, because of the absence of SwrA and in wild strains if the degU $32^{\mathrm{Hy}}$ allele is used as a proxy of DegU P (26).

Although the above data suggest that SwrA does not interact with DegU32 ${ }^{\mathrm{Hy}}$, this is not always true. Indeed, $y$-PGA production is induced by SwrA in the presence of either degU32 $2^{\mathrm{Hy}}$ or $\operatorname{degS200^{\mathrm {Hy}}}(24)$. However, a deep characterization of the differential impacts of the two Hy alleles on $\mathrm{P}_{\mathrm{pgs}}$ has yet to be conducted.

In competence, Hy mutants have been shown to have a negative impact on the overall process in laboratory strains. However, degS/U null mutants were also shown to be non-competent, suggesting the requirement of this TCS in the pathway (9). The current model is the following: DegU P has a negative impact on coms, while unphosphorylated DegU is required, possibly because it mediates the binding of ComK to its own promoter (27). More recently, the $\operatorname{deg} Q^{\text {Hy }}$ allele was shown to negatively affect comS and comK expression in both domestic and wild strains (28). 
In this work we demonstrate that SwrA heavily impacts not only motility and $\mathrm{Y}$-PGA production but

91 also other DegS/U regulated behaviours; SwrA positively modulates DegS/U activity in competence for

92 transformation and reduces aprE transcription. Moreover, we characterized the differential influence of

$93 \mathrm{degU} 32^{\mathrm{Hy}}$ and $\operatorname{degS} 200^{\mathrm{Hy}}$ mutations on pgs transcription. Finally, we once more demonstrate that the

94 degU32 ${ }^{\mathrm{Hy}}$ allele encodes a constitutively active mutant protein whose activity dramatically differs from the

95 phosphorylated DegU P protein. Our results suggest that, as it happened in the past for motility, the use of

96 this mutant may lead to misleading interpretations of the real physiological role of DegS/U TCS in B. subtilis

97 physiology. 
bioRxiv preprint doi: https://doi org/10.1101/2021.05.07.443137; this version posted May 8,2021 . The copyright holder for this preprint (which was not certified by peer review) is the author/funder, who has granted bioRxiv a license to display the preprint in perpetuity. It is made available under aCC-BY 4.0 International license.

\section{RESULTS}

SwrA and motility in undomesticated strains. Our previous work showed that SwrA acts by subverting the impact of DegU P on the fla/che promoter, transforming its action into a positive boost on flagellar gene expression. The functional interaction SwrA-DegU P only occurs with the wild-type phosphorylated form of the response regulator, while the DegU32 ${ }^{\mathrm{Hy}}$ mutant protein does not effectively interface with SwrA at this promoter (16). To generalize this effect also to undomesticated strains, either degU $32^{\mathrm{Hy}}$ or degS200 ${ }^{\mathrm{Hy}}$ mutation was introduced in the transformable com/ ${ }^{\mathrm{Q} 12 \mathrm{~L}}$ mutant of the undomesticated NCIB3610 (29). The introduction of the DegU32 ${ }^{\mathrm{Hy}}$ mutation caused a complete loss of motility, as already shown by StanleyWall and collaborators (26). Conversely, the degS200 ${ }^{\mathrm{Hy}}$ derivative of the undomesticated strain proficiently swam and swarmed, paralleling the results obtained in domestic strain (Fig. S1). The only difference with domestic strains is the presence of a well-defined "lump" of $\gamma$-PGA that can be observed in the central part of the $\operatorname{deg} \mathrm{S}^{\mathrm{Hy}}$ plates in Fig. S1. This characteristic is due to the abundant production of the polymer in DegS200 ${ }^{\mathrm{Hy}}$ mutants, which is much higher than in the degU32 ${ }^{\mathrm{Hy}}$ background. Interestingly, $\mathrm{Y}^{\mathrm{PG} A}$ production was never visible in degS/ $U^{\text {wt }}$ undomesticated strains, although they naturally contain the $\operatorname{deg} Q^{\text {Hy }}$ mutation. This finding suggests that the $\operatorname{deg} Q^{\text {Hy }}$ mutation, which does not impact on the protein structure of DegU, is less effective than the degS200 ${ }^{\mathrm{Hy}}$ mutation in generating DegU P.

Therefore, we concluded that the powerful overturn of the DegU P action on motility genes is a general phenomenon occurring not only in laboratory strains, but also in wild, undomesticated strains, even when the phosphorylation of DegU is maximal.

SwrA and competence for DNA uptake. The voluminous literature data reporting the negative effect of Hy mutations on competence were acquired in domestic $B$. subtilis strains which lack the SwrA protein. To establish whether SwrA has a general role as regulatory factor for DegS/U activity in competence, genetic transformation was analyzed in isogenic mutants differing for the status of the swrA allele as well as for the source of DegU P: either the intact phosphoprotein obtained in the presence of a degS200 ${ }^{\mathrm{Hy}}$ or the mutant DegU32 ${ }^{\text {Hy }}$ protein.

Transformation efficiency was assessed in PB5370 and PB5249, respectively the $s w r A^{-}$and $s w r A^{+}$ versions of the commonly used JH642 domestic strain (30), which do not contain any selectable marker. The $s w r A^{-}$and $s w r A^{+}$isogenic strains did not show any significant difference in transformation efficiency (Fig. 1), but for a slightly better performance of the $s w r A^{+}$strain, PB5249, which was thus taken as reference strain for determining the efficiency of the others. Both strains were transformed with the Hy mutation in either degU or degS and the resulting Hy mutants were transformed with a selectable genomic DNA. As shown in Fig. 1, consistently with literature data, in swrA strains transformation efficiency was abolished by both $\operatorname{deg} \mathrm{U}^{\mathrm{Hy}}$ and $\operatorname{deg} \mathrm{S}^{\mathrm{Hy}}$ mutations (efficiency $0.7 \%$ and $2.7 \%$, respectively). Even in the presence of a functional swrA allele the $\operatorname{deg} \mathrm{U}^{\mathrm{Hy}}$ strain did not substantially modify competence, i.e., the 
$s w r A^{+}$degU $32^{\mathrm{Hy}}$ strain remained non-transformable (0.7\% efficiency). However, the presence of SwrA in the $\operatorname{deg} S^{\mathrm{Hy}}$ strain was sufficient to restore competence to $36 \%$ of efficiency (Fig. 1).

Taken together, these data indicate that if SwrA is functional, competence is reduced but no longer abolished by phosphorylation of DegU. Thus, SwrA is able to modulate the activity of DegU P, partially suppressing its negative effect. This positive action is possible only in the presence of a $\operatorname{deg} S^{\mathrm{Hy}}$ mutation, i.e., in the presence of a phosphorylated wild-type DegU protein.

SwrA and subtilisin expression. The restoration of competence in a $\operatorname{deg} \mathrm{S}^{\mathrm{Hy}}$ strain prompted us to extend our investigation to aprE expression, which is known to be induced by the presence of a Hy mutation in either degS or $\operatorname{deg} U$ (31). As already described, $s w r A^{+}$revertants often arise in the $s w r A^{-}$population upon long incubations and might generate confusing results. To avoid the development of such revertants, a swrA null mutant was created together with an isogenic $s w r A^{+}$strain. To verify whether SwrA has a role also

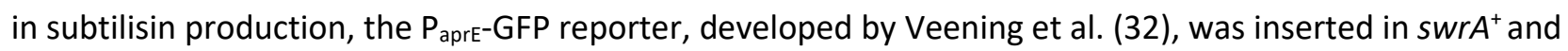
$\triangle$ swrA JH642-derived strains. Analyses were carried out by imaging flow cytometry, which not only allows to quantify the average single cell fluorescence, but also to dissect the aprE-ON and-OFF populations due to heterogeneity in aprE expression $(32,33)$. As the expression of the reporter was not detected in these conditions (data not shown), a degU32 $2^{\mathrm{Hy}}$ or $\operatorname{deg} 5200^{\mathrm{Hy}}$ allele was introduced in each strain. The analyses of the $\mathrm{P}_{\mathrm{aprE}}-\mathrm{GFP} \operatorname{deg} S^{\mathrm{Hy}}$ or $\operatorname{deg} U^{\mathrm{Hy}}$ in both $s w r A^{+}$and $\Delta s w r A$ were focused on the transition phase $\left(\mathrm{T}_{0}\right)$, and 5 and $15 \mathrm{~h}$ later $\left(\mathrm{T}_{5}\right.$ and $\left.\mathrm{T}_{15}\right)$. As shown in Fig. $2 \mathrm{~A}$, in DegU ${ }^{\mathrm{Hy}}$ strains, the percentage of aprE-ON cells did not substantially vary in dependence of the presence of SwrA both at $T_{0}$ and at later time points. Conversely, in DegS ${ }^{\mathrm{Hy}}$ strains the percentage of aprE-ON cells was highly affected by SwrA. The presence of SwrA led to a substantial decrease in the number of ON cells, particularly at $\mathrm{T}_{0}(-70 \%)$. Moreover, the percentage of ON cells was similar between DegU32 ${ }^{\mathrm{Hy}}$ or DegS200 ${ }^{\mathrm{Hy}}$ mutants in $\Delta s w r A$ strains, but it was significantly reduced in the $s w r A^{+}$degS200 ${ }^{\text {Hy }}$ background.

Also, the expression level of $P_{\text {apre, }}$ i.e., the single cell fluorescent intensity, did not vary in the presence or absence of SwrA in DegU ${ }^{\mathrm{Hy}}$ strains; however, in DegS ${ }^{\mathrm{Hy}}$ mutants the presence of SwrA significantly decreased fluorescence intensity (Fig. 2B). Also in this case, there are no appreciable differences in GFP levels among $\Delta s w r A$ strains, while in the $s w r A^{+}$background the degs200 ${ }^{\mathrm{Hy}}$ allele is not as efficient as deg $U^{\mathrm{Hy}}$ in driving aprE expression. A gallery of images of aprE ON and OFF cells acquired during flow cytometry are provided in Fig. S2.

These data allow to conclude that SwrA modulates the activity of DegU P also at the aprE promoter. SwrA reduces the efficacy of DegU P on subtilisin expression. Analogously to what observed in competence, the SwrA-mediated effect only occurs in the presence of a degS ${ }^{\mathrm{Hy}}$ mutation, i.e., in the presence of a wild-type phosphorylated DegU protein. 
$\mathrm{DegS}^{\mathrm{Hy}}$ and DegU $\mathrm{Hy}^{\mathrm{Hy}}$ mutants in pgs expression. The activation of the pgs operon expression is known to

168 depend on the co-presence of at least a degS/ $\mathrm{U}^{\mathrm{Hy}}$ allele and SwrA. However, so far, most of the data have 169 been collected using DegU ${ }^{\mathrm{Hy}}$ mutants, while scant information is given on $\mathrm{P}^{-P G A}$ production in DegS ${ }^{\mathrm{Hy}}$ 170 strains (24). To fill this gap, a $\mathrm{P}_{\mathrm{pgs}}$-sfGFP reporter construct was devised and inserted in locus in the $s w r A^{+}$ 171 laboratory strain. Since no fluorescence was detected in this strain (data not shown), it was further 172 transformed with either $\operatorname{deg} \mathrm{S}^{\mathrm{Hy}}$ or $\operatorname{deg} \mathrm{U}^{\mathrm{Hy}}$ alleles. The Hy strains were grown under vigorous shaking in a 173 glutamate-rich medium that supports $\mathrm{Y}$-PGA production, with periodic sampling over a 48-h prolonged incubation. At relevant time-points, $\mathrm{P}_{\mathrm{pgs}}$ expression was quantified by imaging flow cytometry. In the DegU ${ }^{H y}$ mutant, $\mathrm{P}_{\mathrm{pgs}}$ appeared to be homogeneously active from the beginning of the analysis (2-h post inoculum, data not shown), with intensity reaching a peak at $\mathrm{T}_{-2}$ (8-h post inoculum). This early peak of maximal intensity was followed by a monomodal decline over the next $40 \mathrm{~h}$ (Fig. $3 \mathrm{~A}$ ), with the majority of the population already OFF after $\mathrm{T}_{18}$. Conversely, in the $\mathrm{DegS}^{\mathrm{Hy}}$ strain, $\mathrm{P}_{\mathrm{pgs}}$ activation showed a 2-h delay: cells started displaying fluorescence at $\mathrm{T}_{0}$ (10-h post inoculum), with a gradual increase over time. Intensity reached a peak at $\mathrm{T}_{14}$ which was followed by a slower decline of the GFP signal, which remained however appreciable, in most of the cell population, up to the end of the experiment ( $\left.\mathrm{T}_{38}\right)$ (Fig. 3B). mutants: no transcription is observed in $s w r A^{-}$backgrounds (22-24), and data not shown). However, there is a remarkable difference in the expression profile using the two partner proteins; upon interaction with SwrA, the constitutively active mutant protein DegU $32^{\mathrm{Hy}}$ immediately exerts its pressure on the $p g s$ promoter but the effect is rapidly relieved. In the $\operatorname{deg} S^{\mathrm{Hy}}$ strain, a delay in $p g s$ activation is observed, most 187 likely due to the requirement of the physiological trigger of the signalling pathway. However, once activated, the SwrA-DegU P stimulus on $\mathrm{P}_{\mathrm{pgs}}$ is sustained up to $24 \mathrm{~h}\left(\mathrm{~T}_{14}\right)$, although the intensity of the fluorescent signal is reduced with respect to what observed in cells containing DegU ${ }^{H y}$. These data are in line with our experimental evidence that DegS ${ }^{\text {Hy }}$ strains produce a much higher amount of ${ }^{\gamma}$-PGA (data not shown) and indicate that, although an interaction between SwrA and DegU ${ }^{\mathrm{Hy}}$ occurs, the effect on transcription is considerably different from that obtained when SwrA interacts with DegU P. 


\section{DISCUSSION}

This work extends the array of DegS/U regulated phenotypes in which SwrA plays a pivotal role. The data have been summarized in Table 2. Considering the phenotypes thus far analyzed, SwrA emerges as key modulator of DegS/U on all the promoters tested so far, $P_{\text {apre, }} P_{\text {pgs }}$ (Figs. $2 \& 3$ ) and $P_{\text {fla/che, }}$ (16) (Fig. 4). Notably, SwrA also mitigates the negative effect of DegU P on genetic competence (Fig. 1) and makes $\operatorname{deg} \mathrm{S}^{\mathrm{Hy}} s w r A^{+}$strains easily transformable.

The results shown in this work do not confute literature data obtained in $s w r A^{-}$domestic $B$. subtilis strains (168, JH642, and others) (18). The non-transformability of $\operatorname{deg} U^{\mathrm{Hy}}$ as well as $\operatorname{deg} S^{\mathrm{Hy}} s w r A^{-}$strains is indeed validated in our experimental settings (Fig. 1). Rather, a piece of literature data appears to support our results. In 1991, Hahn and Dubnau, analyzing the impact of degU32 ${ }^{\mathrm{Hy}}$ and degS200 ${ }^{\mathrm{Hy}}$ alleles on $\mathrm{P}_{\text {srfa }}$ expression, could not interpret the fact that, differently from DegU ${ }^{\mathrm{Hy}}$, Degs ${ }^{\mathrm{Hy}}$ did not repress srfA transcription (34). It is tempting to imagine that a high percentage of $s w r A^{+}$revertant cells arose in the DegS ${ }^{\mathrm{Hy}}$ strain used in the experiment, due to the high frequency of phase variation events $\left(10^{-4}\right)(17)$, and in those revertants SwrA was able to mitigate -or supress- the negative effect of DegU P, turning it into a less negative -or positive- signal.

Presently, the main target of DegU P in competence has not been clearly identified, because of the coexistence of at least two possible target genes: $P_{\text {comk }}(8,27,28)$ and $P_{\text {srfA }}(28,34)$. A negative effect of the $\operatorname{deg} Q^{\text {Hy }}$ allele has been evidenced on both promoters, in domestic and undomesticated strains (swrA and $s w r A^{+}$, respectively) (28). Since the $\operatorname{deg} Q^{\mathrm{Hy}}$ mutation increases DegU P levels (5) without impacting on the DegU structure, its interaction with SwrA is preserved. The way in which the effects of SwrA and DegQ are balanced needs to be further analyzed in well-defined genetic backgrounds.

A second fundamental result that emerges from this work is that the DegU $32^{\mathrm{Hy}}$ mutant protein does not behave as the phosphorylated wild-type DegU protein. A proxy for DegU P is represented by the degS200 ${ }^{\mathrm{Hy}}$ mutation, which produces high levels of DegU P without directly modifying the structure of the transcriptional activator DegU. Moreover, from the lack of activation of the pgs promoter in undomesticated strains, which are naturally $\operatorname{swrA}^{+} \operatorname{deg} Q^{\text {Hy }}$ (data not shown), it can be hypothesized that the level of DegU phosphorylation attained in $\operatorname{deg} Q^{\text {Hy }}$ cells is lower compared to that gained with the $\operatorname{degS200^{\mathrm {Hy}}}$ mutation.

From $\mathrm{P}_{\mathrm{pgs}}$ analyzes it can be hypothesized that DegU32 ${ }^{\mathrm{Hy}}$ is able to bind directly to DNA, even before activation of the signalling pathway that would lead to its phosphorylation, i.e., in the nonphosphorylated form (see Fig. 3A). This notion is not novel: Stanely-Wall and collaborators showed that $\mathrm{Y}^{-}$ PGA production in a degU $32^{\mathrm{Hy}}$ background also occurs in a degS null mutant (35). Also in vitro, Mordini et al. (2013) showed that DegU32 ${ }^{\mathrm{Hy}}$ binds to DNA independently from the presence of its cognate kinase. Moreover, the interaction of SwrA (physical or genetical) with the mutant DegU32 ${ }^{\mathrm{Hy}}$ protein is 
228 compromised. Either it does not occur at all, as it appears by the lack of differences between the

229 phenotypes of degU32 ${ }^{\mathrm{Hy}} s w r A^{+}$and $s w r A^{-}$strains in competence, aprE expression and motility (Figs. $1 \& 2$

230 and ref. 16), or it markedly differs from the interaction with DegU P produced by degS200 ${ }^{\mathrm{Hy}}$, as it appears

231 from the differential activation profile of $\mathrm{P}_{\mathrm{pgs}}$ in the two mutants. In any case, the physiological role of

232 DegU P in B. subtilis should be approached using a DegS200 ${ }^{\mathrm{Hy}}$ mutant. This also suggests that our current

233 view of the impact of the DegS/U on $B$. subtilis physiology gained through the use of degU $32^{\mathrm{Hy}}$ mutants

234 might require some revamping, as it happened for motility. 


\section{MATERIALS AND METHODS}

$\underline{\text { Strain construction }}$

237 All strains used in this study are listed in Table 1.

238 PB5630, corresponding to strain DK1042 obtained by D. Kearns and co-workers (29) by introducing the $239 \mathrm{com} / \mathrm{I}^{\mathrm{Q} 12 \mathrm{~L}}$ mutation in the resident plasmid of the undomesticated $\mathrm{NCIB3610}$, was transformed with 240 pLoxSpec/degSU(Hy) and pLoxSpec/degS200 (24). PB5814 and PB5815, respectively, were obtained after 241 selection for spectinomycin resistance $(60 \mu \mathrm{g} / \mathrm{ml})$.

242 The clean deletion of the swrA gene was obtained by transforming PB5249 with pCC $\Delta$ swrA, a non243 replicative plasmid that, completely removing the swrA ORF, inserts a kanamycin resistance gene upstream 244 of the swrA promoter to control the expression of the downstream minJ gene. pCC $\Delta$ swrA plasmid was 245 obtained through the following steps: a PCR fragment comprising the region upstream the swrA gene, containing all the regulatory elements, was amplified from PB5249 genomic DNA with primers UPPromA/E (EcoRI)5'-ccgaattctttgtgcttaaagagattatggatc-3' and CC_A_rev (Xhol) 5'aacgctcgagttgtgaacccccattttctttatacagataagcac-3'; the initial part of the following ORF, minJ, was amplified from the same source with primers CC_B_for (Xhol) 5'-accgctcgaggtgtctgttcaatggggaattgaactgttaaaaagc-3' and CC_C_rev (Smal) 5'-tcccccggggtttgccagctgctgtccgatcg-3'. The two products were digested with Xhol (restriction sites underlined) and ligated. The $934 \mathrm{bp}$ resulting product was inserted between the EcoRI and Smal sites of the pJM114-derived pCC1 (21). The plasmid pCC $\Delta$ swrA, verified by multiple restriction digestion and by sequencing of the relevant portions.

The plasmid pCC $\Delta$ swrA was used to transform PB5249. PB5606 was obtained by selecting one clone for kanamycin $(2 \mu \mathrm{g} / \mathrm{ml})$ resistance; deletion of the coding sequence of $s w r A$ and the integrity of its promoter and $\min J$ were verified by PCR and DNA sequencing.

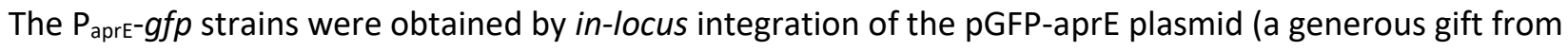
Prof. J.W. Veening, ref. 32) into the chromosome of $s w r A^{+}$and $\Delta s w r A$ isogenic strains, respectively PB5393 (21) and PB5606 (described above), both carrying a kanamycin resistance gene upstream of the swrA 260 promoter region. The resulting strains were named PB5717 and PB5719, respectively (Table 1). degU32(Hy) 261 and degS200(Hy) alleles, were introduced in PB5717 and PB5719 by transformation with pLoxSpec/degSUHy) and pLoxSpec/degS200 (24) and selection for spectinomycin resistance (60 $\mathrm{mg} / \mathrm{ml})$. In the derived strains, PB5720, PB5722, PB5723 and PB5725 (Table 1), the single copy insertion of each construct was assessed.

The $\mathrm{P}_{\mathrm{pgs}} \mathrm{S}$ SFgfp strains were obtained using a modified pMutin vector (pMATywsC). The construction of the plasmid occurred in multiple steps. First, in the pMutin-GFP vector (ECE149, obtained from the Bacillus genetic stock centre, http://www.bgsc.org// the gfp gene was substituted by Gibson assembly with a super 
bioRxiv preprint doi: https://doi.org/10.1101/2021.05.07.443137: this version posted May 8,2021 . The copyriaht holder for this preprint (which was not certified by peer review) is the author/funder, who has granted bioRxiv a license to display the preprint in perpetuity. It is made available under aCC-BY 4.0 International license.

268 folder version of the GFP (SFgfp) amplified from pECE323 plasmid (Bacillus genetic stock centre) with primers RXeGFPda321- 5'-ggctgcactagtgctcgaattcattatttataaagttcgtccataccgtg-3' and FXeGFPda321- 5'tcggccggaaggagatatacatatgtcaaaaggagaagaactttttacag- $3^{\prime}$ to give pMutinsfGFP. The $5^{\prime}$ portion of $y w s C$ together with the Phyperspank promoter were inserted in the resulting pMutinsfGFP through a tripartite Gibson assembly. The Phyperspank promoter was amplified from plasmid Phyp.RO.sfGFP(sp).Lacl_operon (36) using primers PHypFor 5'-agcttccaagaaagatatccctcggatacccttactctgttg-3' and

PHypRev 5'-ggctataatgagtaaccacatgtttgtcctccttattagttaatc-3'; the 5' portion of ywsC (647 bp) was amplified

from PB5249

chromosomal

DNA

using

primers ywsCFor

5 RBS and initial codons were translationally fused to the sfGFP using the partially overlapping oligos

ccctgataacgcttctctggaattcccgggatccccagcttgttgatacactaatgcttttatatagggaaaaggtggtgaactactatgTCAAAAGGAG - 3' and oligoREVSpoVG 5'-

CTCCTTTTGAcatagtagttcaccaccttttccctatataaaagcattagtgtatcaacaagctggggatcccgggaattccagagaagcgttatcaggg - 3', derived from the pJM116 vector (37) The final construct was verified by sequencing and saved as pMATywsC. This plasmid was used to transform PB5249 (swrA $A^{+}$and PB5370 (swrA $)$, using erythromycin resistance $(5 \mathrm{\mu g} / \mathrm{ml})$ for selection, resulting in PB5741 and PB5742 strains, respectively. degU32(Hy) and degS200(Hy) alleles were introduced in PB5741 by transformation with pLoxSpec/degSU(Hy) and pLoxSpec/degS200 (24) by spectinomycin resistance $(60 \mu \mathrm{g} / \mathrm{ml})$ selection, giving rise to PB5743 and PB5745, respectively. The single copy insertion of each construct was assessed.

290 Cells were inoculated in $\mathrm{LM}$ ( $\mathrm{LB}$ supplemented with $\mathrm{MgSO}_{4}, 9 \mu \mathrm{M}$; tryptophan, $50 \mu \mathrm{g} / \mathrm{mL}$; phenylalanine, 50 $291 \mu \mathrm{g} / \mathrm{mL})$ at $\mathrm{OD}_{600}=0.2$ and grown at $37^{\circ} \mathrm{C}$ shaking. At $\mathrm{OD}_{600}=1$, cells were diluted 1:20 in $\mathrm{MD}\left(\mathrm{K}_{2} \mathrm{HPO}_{4}, 9.8\right.$ $\mathrm{mg} / \mathrm{ml} ; \mathrm{KH}_{2} \mathrm{PO}_{4}, 5.52 \mathrm{mg} / \mathrm{ml} ; \mathrm{Na}_{3}$ Citrate $5 \mathrm{H}_{2} \mathrm{O}, 0.92 \mathrm{mg} / \mathrm{ml}$; glucose, $20 \mathrm{mg} / \mathrm{ml}$; tryptophan, $50 \mu \mathrm{g} / \mathrm{ml}$; phenylalanine, $50 \mathrm{\mu g} / \mathrm{ml}$; ferric ammonium citrate, $11 \mu \mathrm{g} / \mathrm{ml}$; K-aspartate, $2.5 \mathrm{mg} / \mathrm{ml}$; $\mathrm{MgSO}_{4}, 0.36 \mathrm{mg} / \mathrm{ml}$ ) and grown at $37^{\circ} \mathrm{C}$ until stationary phase $\left(T_{0}\right)$. About $200 \mathrm{ng}$ of chloramphenicol $(\mathrm{Cm})$-selectable $B$. subtilis chromosomal DNA was added to $0.5 \mathrm{ml}$ cells which were further incubated for $1.5 \mathrm{~h}$ at $37^{\circ} \mathrm{C}$ with shaking. Transformants were isolated on $5 \mathrm{mg} / \mathrm{ml}$ chloramphenicol on several selective plates. Resistant colonies were counted and related to cell density at $\mathrm{T}_{0}$ to calculate the transformation efficiency, taking into account each dilution step before plating. Data shown in Fig. 1 represent the average of three independent experiments. 
301 For the analysis of $\mathrm{P}_{\text {apre }}$ activity, cells were inoculated in Shaeffer's sporulation medium (38) at $0.2 \mathrm{OD}_{600}$ and 302 grown at $37^{\circ} \mathrm{C}$ under continuous shaking for $20 \mathrm{~h}$. Aliquots were collected every $60^{\prime}$ for $\mathrm{OD}_{600}$ readings; at 303 the transition point (5h), 5 and $15 \mathrm{~h}$ later, $10 \%$ glycerol (final concentration) was added to culture aliquots 304 for storage at $-20^{\circ} \mathrm{C}$.

305 For the analysis of $P_{\mathrm{pgs}}$ activity, cells were inoculated in E-medium (39) at $\mathrm{OD}_{600}=0.1$ and grown at $37^{\circ} \mathrm{C}$ 306 under continuous shaking for $48 \mathrm{~h}$. Aliquots were collected at 2-h intervals for $\mathrm{OD}_{600}$ readings and direct 307 cytofluorimetric analyses. Before analyses, fresh and/or frozen samples were centrifuged for 5 minutes at 30814000 xg; cell pellets were re-suspended in D-PBS for flow cytometry (Gibco).

309 Samples were acquired on an Amnis ${ }^{\circledR}$ ImageStream ${ }^{\circledR} \mathrm{X}$ Mk II Imaging Flow Cytometer using the INSPIRE software with the following set up: Channel 02 (GFP fluorescence), Channel 06 (scattering channel); the Brightfield was visualized on Channel 01 and on Channel 05, depending on the GFP expression level, to avoid interference from Channel 02 . The $488 \mathrm{~nm}$ laser was used at either $50 \mathrm{~mW}$ or $100 \mathrm{~mW}$ power, according to the GFP expression level, in order to avoid sensor saturation. The flow rate was set to low speed/high sensitivity and images were taken at 60X magnification. For each sample at least 10000 events were acquired.

All data were analyzed using the IDEAS software (version 6.2). In-focus events were gated in a histogram displaying the Gradient RMS_M01_Ch01 on the x-axis. A plot of the Area versus Aspect Ratio Intensity in the Brightfield channel was used to exclude doublets from the analysis. A plot of the Area versus Intensity in the Scattering channel was used to exclude events characterized by high scatter such as beads. To avoid any bias due to cell size in evaluating fluorescence intensity, the GFP level of each cell was calculated through the Median Pixel feature on the fluorescence channel. The threshold value to distinguish the ON population was set at the maximum autofluorescence of a non-fluorescent population used as negative control (OFF). Data presented in Figs. 2 and 3 represent the average of three independent experiments.

\section{ACKNOWLEDGEMENTS}

326 This research was supported by the Italian Ministry of Education, University and Research (MIUR): 327 Dipartimenti di Eccellenza Program (2018-2022) - Dept. of Biology and Biotechnology "L. Spallanzani", 328 University of Pavia. Authors are grateful to Prof. J. W. Veening for the $P_{\text {apre }}$ plasmid. The contribution of 329 Erlinda Rama, Matteo Cavaletti, Jessica Bollini, Laura Nucci is acknowledged. We also thank Dr A. Azzalin, from the departmental imaging facility, and Dr A. Serra, from Luminex Corporation, for support with the 


\begin{tabular}{|c|c|c|}
\hline Strain & Relevant genotype & Source or reference \\
\hline PB5630 & $\operatorname{com} / l^{0.12 L}$ & BGSC \# 3 A38 \\
\hline PB 5814 & 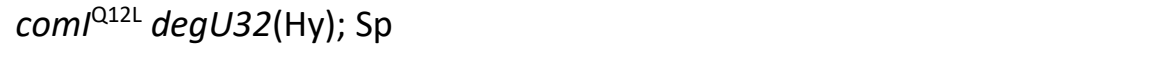 & This study \\
\hline PB 5815 & 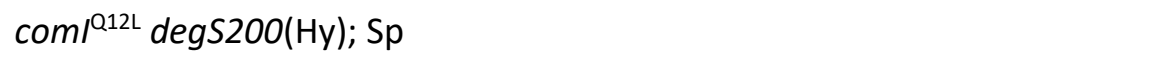 & This study \\
\hline PB5249 & $\operatorname{trp} C 2$ pheA1 swrA $A^{+}$ & (Calvio et al., 2008) \\
\hline PB5370 & $\operatorname{trpC2}$ pheA1 swrA- & (Calvio et al., 2008) \\
\hline PB5606 & $\operatorname{trpC2}$ pheA1 $\triangle s w r A ; \mathrm{Km}$ & This study \\
\hline PB5383 & $\operatorname{trpC2}$ pheA1 swrA ${ }^{+} \operatorname{deg} U 32(\mathrm{Hy}) ; \mathrm{Sp}$ & (Osera et al., 2009) \\
\hline PB5384 & $\operatorname{trpC2}$ pheA1 swrA- degU32(Hy); Sp & (Osera et al., 2009) \\
\hline PB5390 & 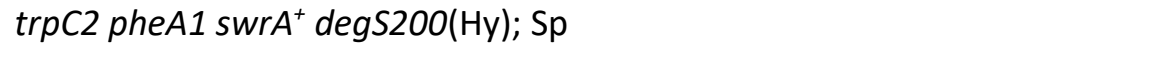 & (Osera et al., 2009) \\
\hline PB5391 & $\operatorname{trpC2}$ pheA1 swrA- $\operatorname{degS} 200(\mathrm{Hy}) ; \mathrm{Sp}$ & (Osera et al., 2009) \\
\hline PB5717 & $\operatorname{trpC2}$ pheA1 swrA $P_{\text {apre- }}-g f p ; \mathrm{Km}, \mathrm{Cm}$ & (This study) \\
\hline PB5719 & $\operatorname{trpC2}$ pheA1 $\Delta s w r A P_{\text {apre }}-g f p ; \mathrm{Km}, \mathrm{Cm}$ & (This study) \\
\hline PB5720 & 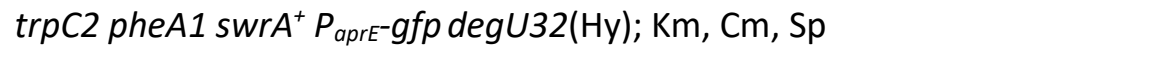 & (This study) \\
\hline PB5722 & $\operatorname{trpC2}$ pheA1 $\Delta$ swrA $P_{a p r E}-g f p \operatorname{deg} U 32(\mathrm{Hy}) ; \mathrm{Km}, \mathrm{Cm}, \mathrm{Sp}$ & (This study) \\
\hline PB5723 & $\operatorname{trpC2}$ pheA1 swrA $P_{\text {apre }}-g f p \operatorname{degS} 200(\mathrm{Hy}) ; \mathrm{Km}, \mathrm{Cm}, \mathrm{Sp}$ & (This study) \\
\hline PB5725 & $\operatorname{trpC2}$ pheA1 $\triangle$ swrA $P_{\text {apre }}-g f p$ degS200(Hy); Km, Cm, Sp & (This study) \\
\hline PB5741 & $\operatorname{trpC2}$ pheA1 swrA ${ }^{+}$ywsC::RBSspoVG:sfGFP_Phyperspank::ywsC; Em & (This study) \\
\hline PB5742 & trpC2 pheA1 swrA- ywsC::RBSspoVG:sfGFP_Phyperspank::ywsC; Em & (This study) \\
\hline PB5743 & 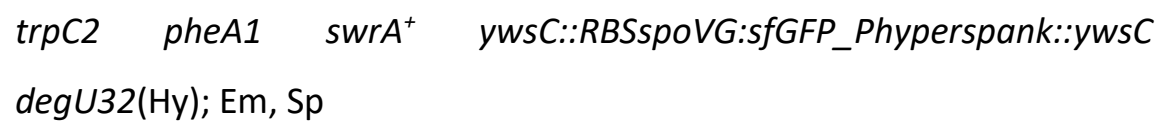 & (This study) \\
\hline PB5745 & 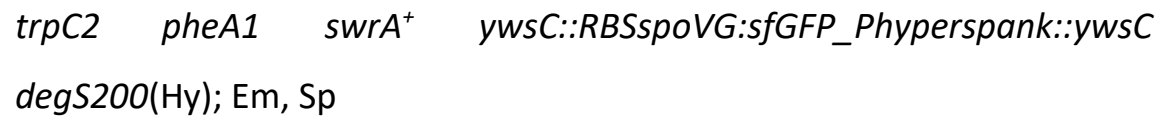 & (This study) \\
\hline
\end{tabular}




\begin{tabular}{|c|c|c|c|c|}
\hline \multirow[b]{2}{*}{ Target } & \multirow[b]{2}{*}{$\operatorname{deg} S / U^{\mathrm{wt}} s w r A^{-}$} & \multicolumn{2}{|c|}{ Effect of DegU P [degS(Hy)] } & \\
\hline & & swrA- & swrA ${ }^{+}$ & \\
\hline $\mathrm{P}_{\text {fla/che }}$ & motile & NEGATIVE (non-motile) & POSITIVE (hyperflagellation) & $\begin{array}{c}\text { Mordini et al, } \\
2013\end{array}$ \\
\hline $\mathrm{P}_{\text {apre }}$ & no expression & POSITIVE (production) & PARTIALLY NEGATIVE (-38\%) & Fig. 2 \\
\hline $\mathrm{P}_{p g s}$ & no expression & NONE & POSITIVE (mucoid colonies) & Fig. 3 \\
\hline Competence & competent & NEGATIVE (non-competent) & PARTIALLY POSITIVE (+37\%) & Fig. 1 \\
\hline
\end{tabular}


bioRxiv preprint doi: https:/doi org/10.1101/2021.05.07 443137· this version posted May 8 2021. The copyright holder for this preprint (which was not certified by peer review) is the author/funder, who has granted bioRxiv a license to display the preprint in perpetuity. It is made available under aCC-BY 4.0 International license.

\section{REFERENCES}

1. Mitrophanov AY, Groisman EA. 2008. Signal integration in bacterial two-component regulatory systems. Genes \& development 22:2601-2611.

2. Msadek T, Kunst F, Henner D, Klier A, Rapoport G, Dedonder R. 1990. Signal transduction pathway controlling synthesis of a class of degradative enzymes in Bacillus subtilis: expression of the regulatory genes and analysis of mutations in degS and degU. J Bacteriol 172:824-34.

3. Ogura M, Yamaguchi H, Yoshida Ki, Fujita Y, Tanaka T. 2001. DNA microarray analysis of Bacillus subtilis DegU, ComA and PhoP regulons: an approach to comprehensive analysis of B.subtilis twocomponent regulatory systems. Nucleic Acids Res 29:3804-13.

4. Mäder U, Antelmann H, Buder T, Dahl M, Hecker M, Homuth G. 2002. Bacillus subtilis functional genomics: genome-wide analysis of the DegS-DegU regulon by transcriptomics and proteomics. Mol Genet Genomics 268:455-67.

5. Kobayashi K. 2007. Gradual activation of the response regulator DegU controls serial expression of genes for flagellum formation and biofilm formation in Bacillus subtilis. Molecular Microbiology 66:395-409.

6. Kunst F, Pascal M, Lepesant-Kejzlarova J, Lepesant J, Billault A, Dedonder R. 1974. Pleiotropic mutations affecting sporulation conditions and the syntheses of extracellular enzymes in Bacillus subtilis 168 . Biochimie 56:1481-9.

7. Dahl M, Msadek T, Kunst F, Rapoport G. 1991. Mutational analysis of the Bacillus subtilis DegU regulator and its phosphorylation by the DegS protein kinase. J Bacteriol 173:2539-47.

8. Dahl M, Msadek T, Kunst F, Rapoport G. 1992. The phosphorylation state of the DegU response regulator acts as a molecular switch allowing either degradative enzyme synthesis or expression of genetic competence in Bacillus subtilis. J Biol Chem 267:14509-14.

9. van Sinderen D, Venema G. 1994. comK acts as an autoregulatory control switch in the signal transduction route to competence in Bacillus subtilis. J Bacteriol 176:5762-70.

10. Amati G, Bisicchia P, Galizzi A. 2004. DegU-P represses expression of the motility fla-che operon in Bacillus subtilis. J Bacteriol 186:6003-14.

11. Mukai K, Kawata-Mukai M, Tanaka T. 1992. Stabilization of phosphorylated Bacillus subtilis DegU by DegR. J Bacteriol 174:7954-62.

12. Yang M, Ferrari E, Chen E, Henner D. 1986. Identification of the pleiotropic sacQ gene of Bacillus subtilis. J Bacteriol 166:113-9. 
13. McLoon AL, Guttenplan SB, Kearns DB, Kolter R, Losick R. 2011. Tracing the domestication of a biofilm-forming bacterium. J Bacteriol 193:2027-34.

14. Henner DJ, Yang M, Ferrari E. 1988. Localization of Bacillus subtilis $\operatorname{sacU}(\mathrm{Hy})$ mutations to two linked genes with similarities to the conserved procaryotic family of two-component signalling systems. J Bacteriol 170:5102-9.

15. Tanaka T, Kawata M, Mukai K. 1991. Altered phosphorylation of Bacillus subtilis DegU caused by single amino acid changes in DegS. J Bacteriol 173:5507-15.

16. Mordini S, Osera C, Marini S, Scavone F, Bellazzi R, Galizzi A, Calvio C. 2013. The role of SwrA, DegU and $\mathrm{P}(\mathrm{D} 3)$ in $\mathrm{fla} / \mathrm{che}$ expression in B. subtilis. PLoS One 8:e85065.

17. Kearns DB, Chu F, Rudner R, Losick R. 2004. Genes governing swarming in Bacillus subtilis and evidence for a phase variation mechanism controlling surface motility. Mol Microbiol 52:357-69.

18. Calvio C, Celandroni F, Ghelardi E, Amati G, Salvetti S, Ceciliani F, Galizzi A, Senesi S. 2005. Swarming differentiation and swimming motility in Bacillus subtilis are controlled by swrA, a newly identified dicistronic operon. J Bacteriol 187:5356-5366.

19. Zeigler DR, Prágai Z, Rodriguez S, Chevreux B, Muffler A, Albert T, Bai R, Wyss M, Perkins JB. 2008. The origins of 168, W23, and other Bacillus subtilis legacy strains. J Bacteriol 190:6983-95.

20. Kearns DB, Losick R. 2005. Cell population heterogeneity during growth of Bacillus subtilis. Genes Dev 19:3083-94.

21. Calvio C, Osera C, Amati G, Galizzi A. 2008. Autoregulation of swrAA and motility in Bacillus subtilis. J Bacteriol 190:5720-5728.

22. Urushibata Y, Tokuyama S, Tahara Y. 2002. Difference in transcription levels of cap genes for gamma-polyglutamic acid production between Bacillus subtilis IFO 16449 and Marburg 168. J Biosci Bioeng 93:252-4.

23. Stanley N, Lazazzera B. 2005. Defining the genetic differences between wild and domestic strains of Bacillus subtilis that affect poly-gamma-dl-glutamic acid production and biofilm formation. Mol Microbiol 57:1143-58.

24. Osera C, Amati G, Calvio C, Galizzi A. 2009. SwrAA activates poly-gamma-glutamate synthesis in addition to swarming in Bacillus subtilis. Microbiology-Sgm 155:2282-2287.

25. Ogura M, Tsukahara K. 2012. SwrA regulates assembly of Bacillus subtilis DegU via its interaction with N-terminal domain of DegU. J Biochem 151:643-655. 
bioRxiv preprint doi: https:/doi org/10.1101/2021.05.07 443137· this version posted May 8 2021. The copyriaht holder for this preprint (which was not certified by peer review) is the author/funder, who has granted bioRxiv a license to display the preprint in perpetuity. It is made available under aCC-BY 4.0 International license.

26. Verhamme D, Kiley T, Stanley-Wall N. 2007. DegU co-ordinates multicellular behaviour exhibited by Bacillus subtilis. Mol Microbiol 65:554-68.

27. Hamoen LW, Van Werkhoven AF, Venema G, Dubnau D. 2000. The pleiotropic response regulator DegU functions as a priming protein in competence development in Bacillus subtilis. Proc Natl Acad Sci U S A 97:9246-51.

28. Miras M, Dubnau D. 2016. A DegU-P and DegQ-Dependent Regulatory Pathway for the K-state in Bacillus subtilis. Frontiers in Microbiology 7:1868.

29. Konkol MA, Blair KM, Kearns DB. 2013. Plasmid-Encoded Coml Inhibits Competence in the Ancestral 3610 Strain of Bacillus subtilis. J Bacteriol 195:4085-4093.

30. Srivatsan A, Han Y, Peng J, Tehranchi AK, Gibbs R, Wang JD, Chen R. 2008. High-precision, wholegenome sequencing of laboratory strains facilitates genetic studies. PLoS Genet 4:e1000139.

31. Henner DJ, Ferrari E, Perego M, Hoch JA. 1988. Location of the targets of the hpr-97, sacU32(Hy), and sacQ36(Hy) mutations in upstream regions of the subtilisin promoter. J Bacteriol 170:296-300.

32. Veening J, Igoshin O, Eijlander R, Nijland R, Hamoen L, Kuipers O. 2008. Transient heterogeneity in extracellular protease production by Bacillus subtilis. Mol Syst Biol 4:184.

33. Veening J, Hamoen L, Kuipers O. 2005. Phosphatases modulate the bistable sporulation gene expression pattern in Bacillus subtilis. Mol Microbiol 56:1481-94.

34. Hahn J, Dubnau D. 1991. Growth stage signal transduction and the requirements for srfA induction in development of competence. J Bacteriol 173:7275-7282.

35. Cairns LS, Marlow VL, Bissett E, Ostrowski A, Stanley-Wall NR. 2013. A mechanical signal transmitted by the flagellum controls signalling in Bacillus subtilis. Mol Microbiol 90:6-21.

36. Guiziou S, Sauveplane V, Chang HJ, Clerté C, Declerck N, Jules M, Bonnet J. 2016. A part toolbox to tune genetic expression in Bacillus subtilis. Nucleic Acids Res 44:7495-508

37. Perego M. 1993. Integrational Vectors for Genetic Manipulation in Bacillus subtilis, p 615-624. In Bacillus subtilis and Other Gram-Positive Bacteria (eds A.L. Sonenshein, J.A. Hoch and R. Losick).

38. Harwood CR, Cutting SM. 1990. Molecular Biological Methods for Bacillus. John Wiley and Sons, Chichester.

39. Scoffone V, Dondi D, Biino G, Borghese G, Pasini D, Galizzi A, Calvio C. 2013. Knockout of pgdS and ggt genes improves gamma-PGA yield in B. subtilis. Biotechnol Bioeng 110:2006-12. 


\section{FIGURE LEGENDS}

Fig. 1. Transformation efficiency. Competence was evaluated in laboratory strains derived from JH642 (swrA- $\operatorname{deg} Q^{w t} \operatorname{trpC1}$ pheA2), differing for the status of the degS/U and swrA alleles (listed in Table 1), by counting resistant colonies obtained by transformation with selectable genomic DNA. Each experiment is the average of at least three independent replicates; error bars account for the standard error of the mean. The genotype of each strain is given on the x-axis. In each experiment, $100 \%$ efficiency was assumed for the $s w r A^{+}$strain (PB5249).

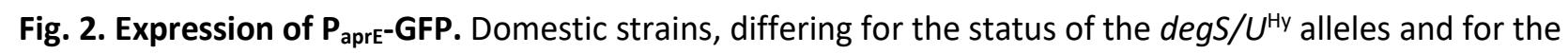
presence of a functional swrA gene, were analysed by imaging flow cytometry to evaluate the percentage of GFP-ON/OFF cells and the peak of fluorescence intensity. Cultures were sampled at the transition point $\left(T_{0}\right), 5$ and 15 hours later $\left(T_{5}\right.$ and $\left.T_{15}\right)$, as indicated below each graph, where the swrA status is also

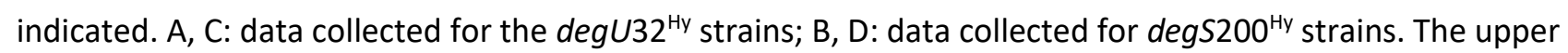
panels, $A$ and $B$, represent the percentage of cells expressing the reporter gene (ON-population). The lower panels, $C$ and $D$, show the peak of intensity of the $\mathrm{ON}$-population. Values represent the average of at least three independent replicates; error bars account for the standard error of the mean.

Fig. 3. Expression profile of $\mathbf{P}_{\mathrm{pgs}}$-GFP. Strains (A) $s w r A^{+} \operatorname{deg} U^{\mathrm{Hy}}$ and (B) $s w r A^{+} \operatorname{deg} S^{\mathrm{Hy}}$ were grown in Emedium and cells were collected for imaging flow cytometry at different time points. The colour of the plots refers to the collection time (in $\mathrm{h}$ relative to the transition point), which is indicated in each graph. A dashed line marks the $\mathrm{ON}$ threshold. The intensity values, represented in logarithmic scale on the $\mathrm{x}$-axis, refer to the median pixel intensity of each single event.

Fig. 4. SwrA effects on DegS/U regulated genes. The schematic representations above summarizes the data collected on aprE, pgs and fla/che transcription on the global effects exerted DegU P alone (left) and with SwrA (right). The size of the curved arrows in front of each gene is indicative of the efficiency of transcription. Symbols are described in the box at the bottom. 
bioRxiv preprint doi: https://doi.org/10.1101/2021.05.07.443137; this version posted May 8, 2021. The copyright holder for this preprint (which was not certified by peer review) is the author/funder, who has granted bioRxiv a license to display the preprint in perpetuity. It is made available under aCC-BY 4.0 International license.

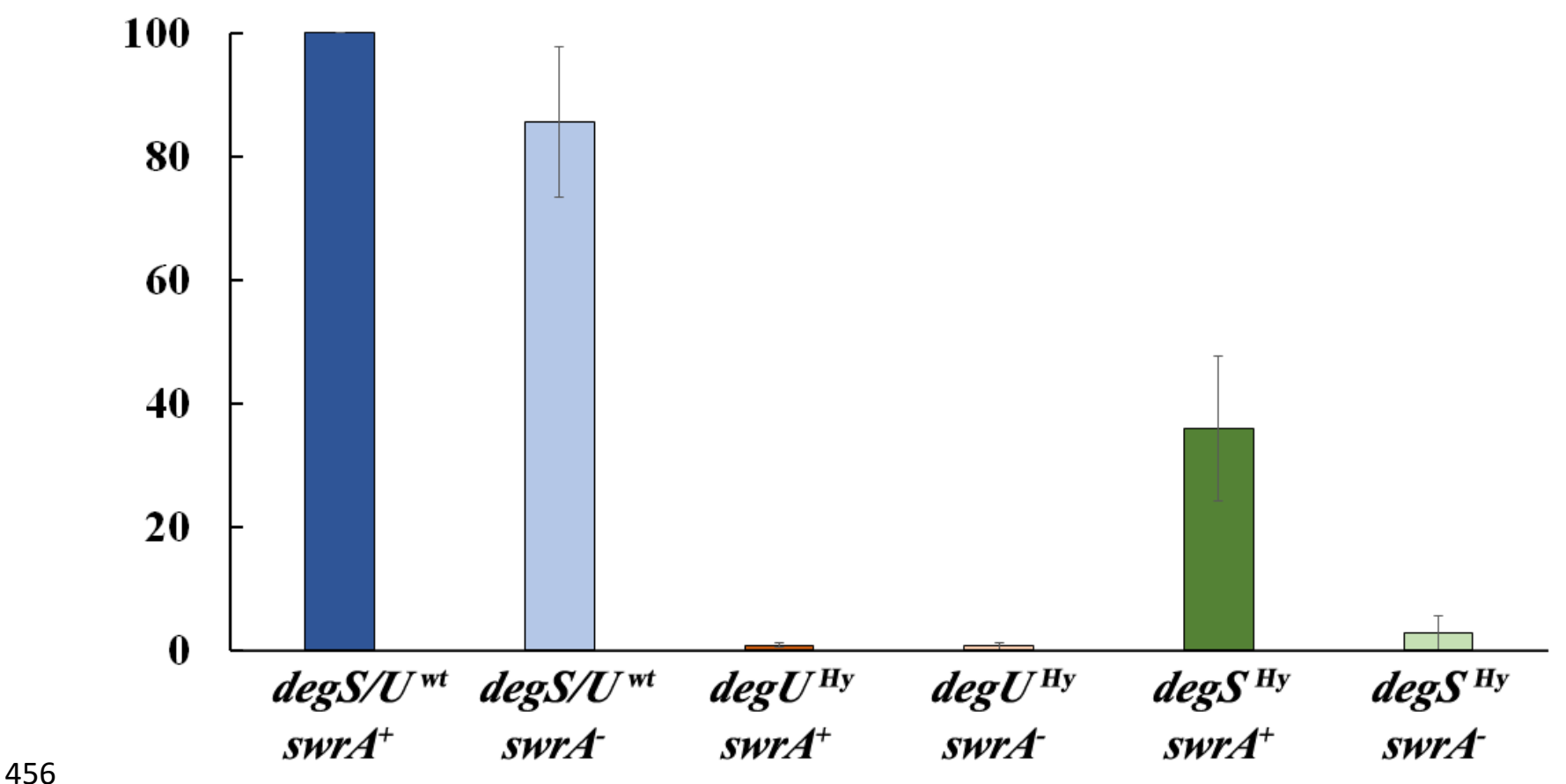


A $\quad$ aprE-ON population in $\operatorname{deg} U^{\mathrm{Hy}}$ strains
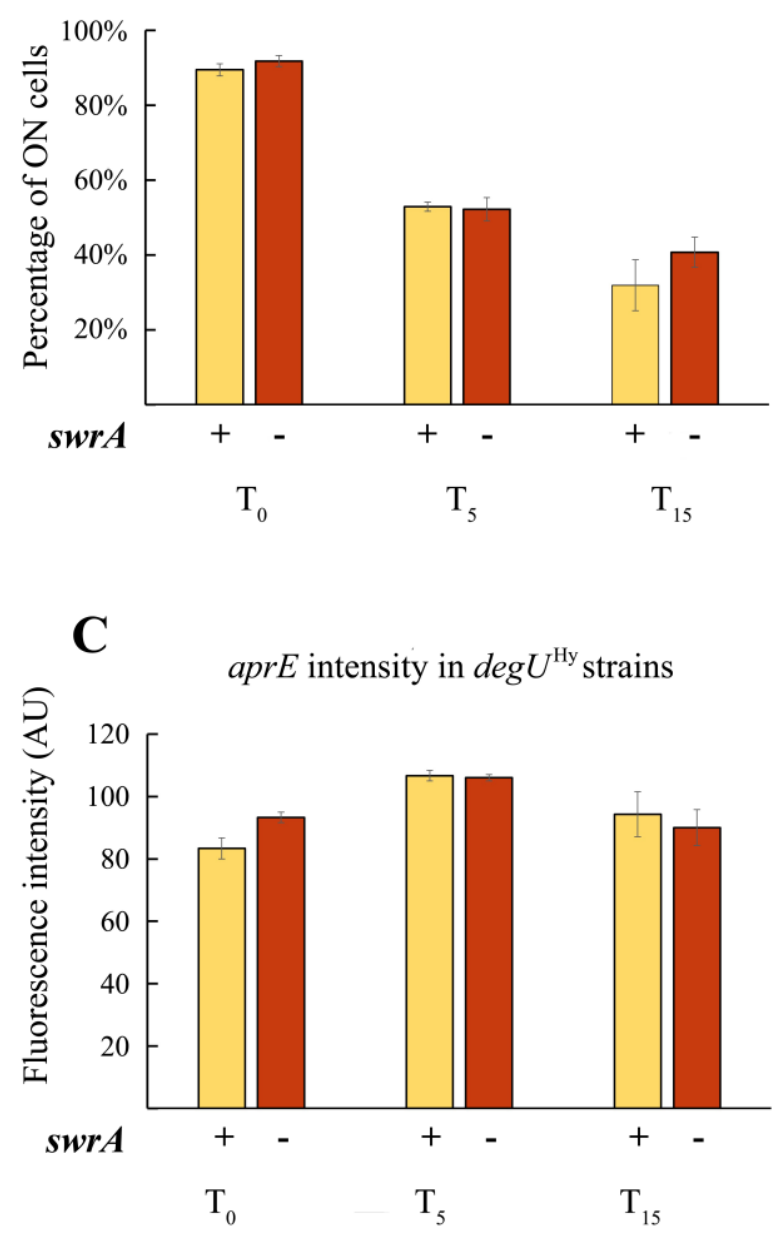

B

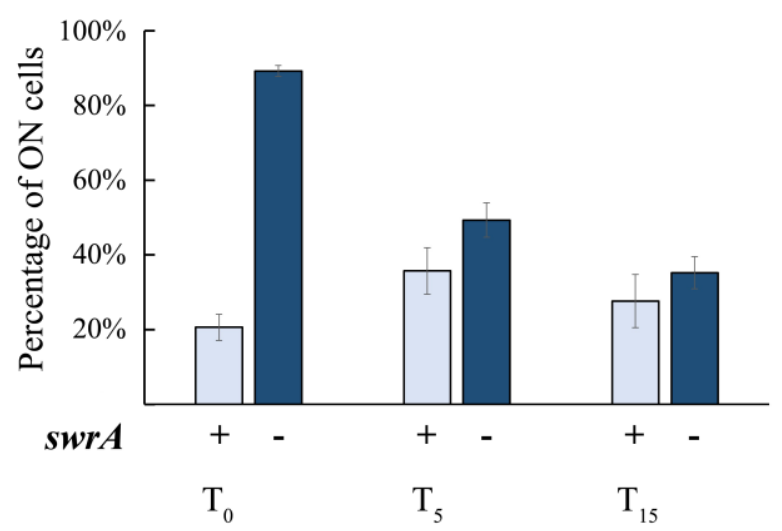

D

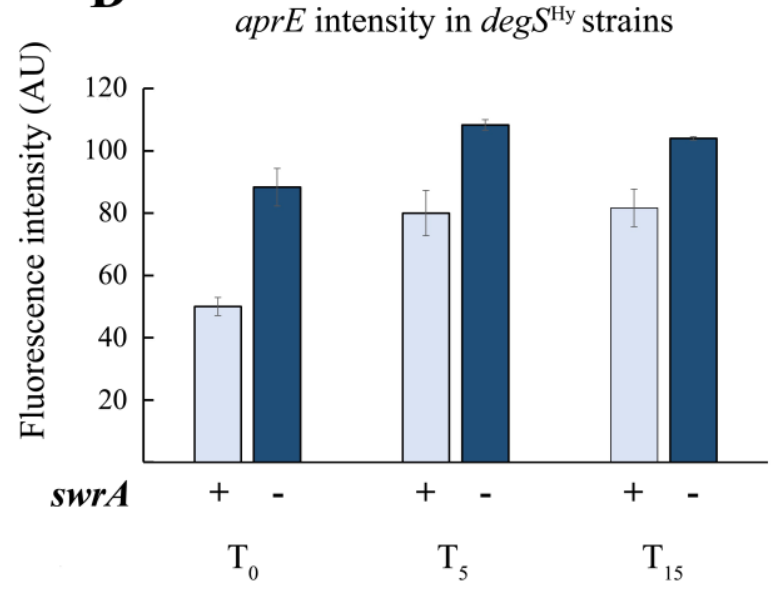


bioRxiv preprint doi: https://doi.org/10.1101/2021.05.07.443137; this version posted May 8, 2021. The copyright holder for this preprint (which was not certified by peer review) is the author/funder, who has granted bioRxiv a license to display the preprint in perpetuity. It is made available under aCC-BY 4.0 International license.

$\boldsymbol{A}$

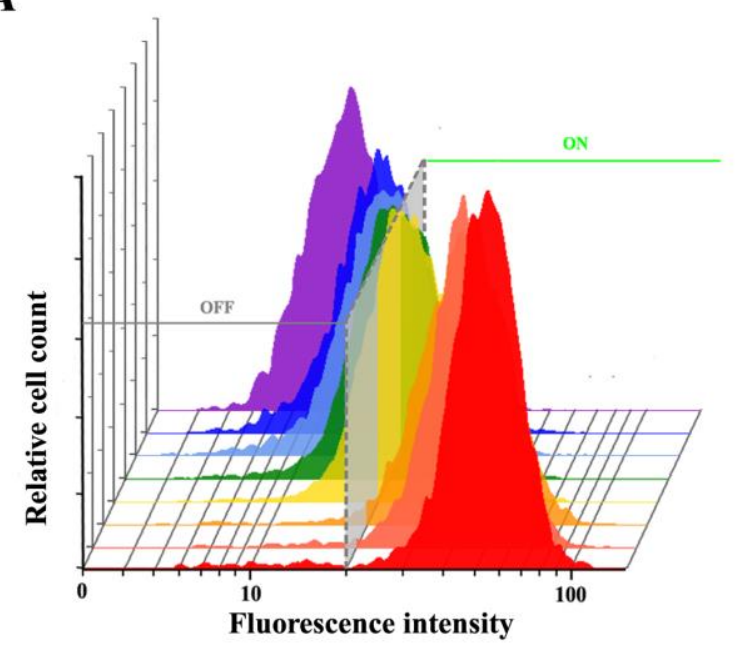

$\boldsymbol{B}$

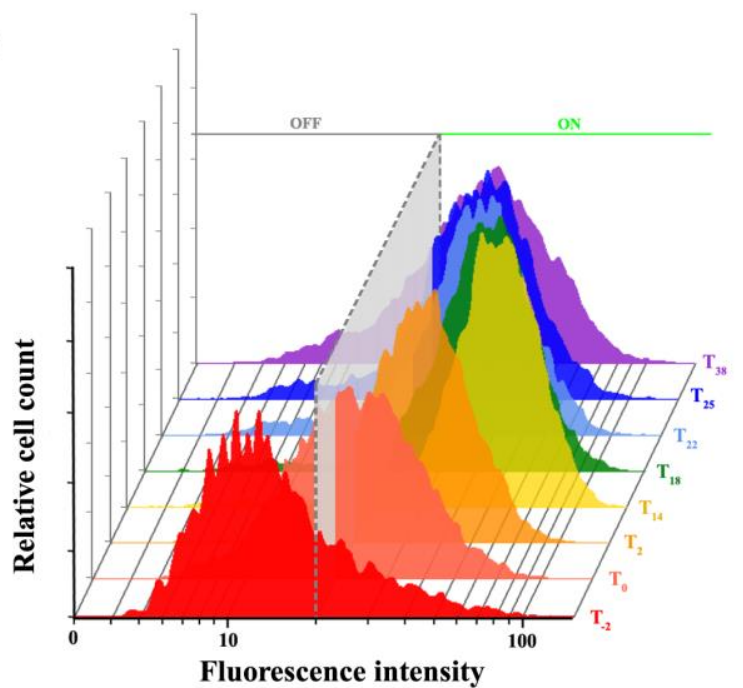


bioRxiv preprint doi: https://doi.org/10.1101/2021.05.07.443137 this version posted May 8, 2021. The copyright holder for this preprint (which was not certified by peer review) is the author/funder, who has granted bioRxiv a license to display the preprint in perpetuity. It is made available under aCC-BY 4.0 International license.
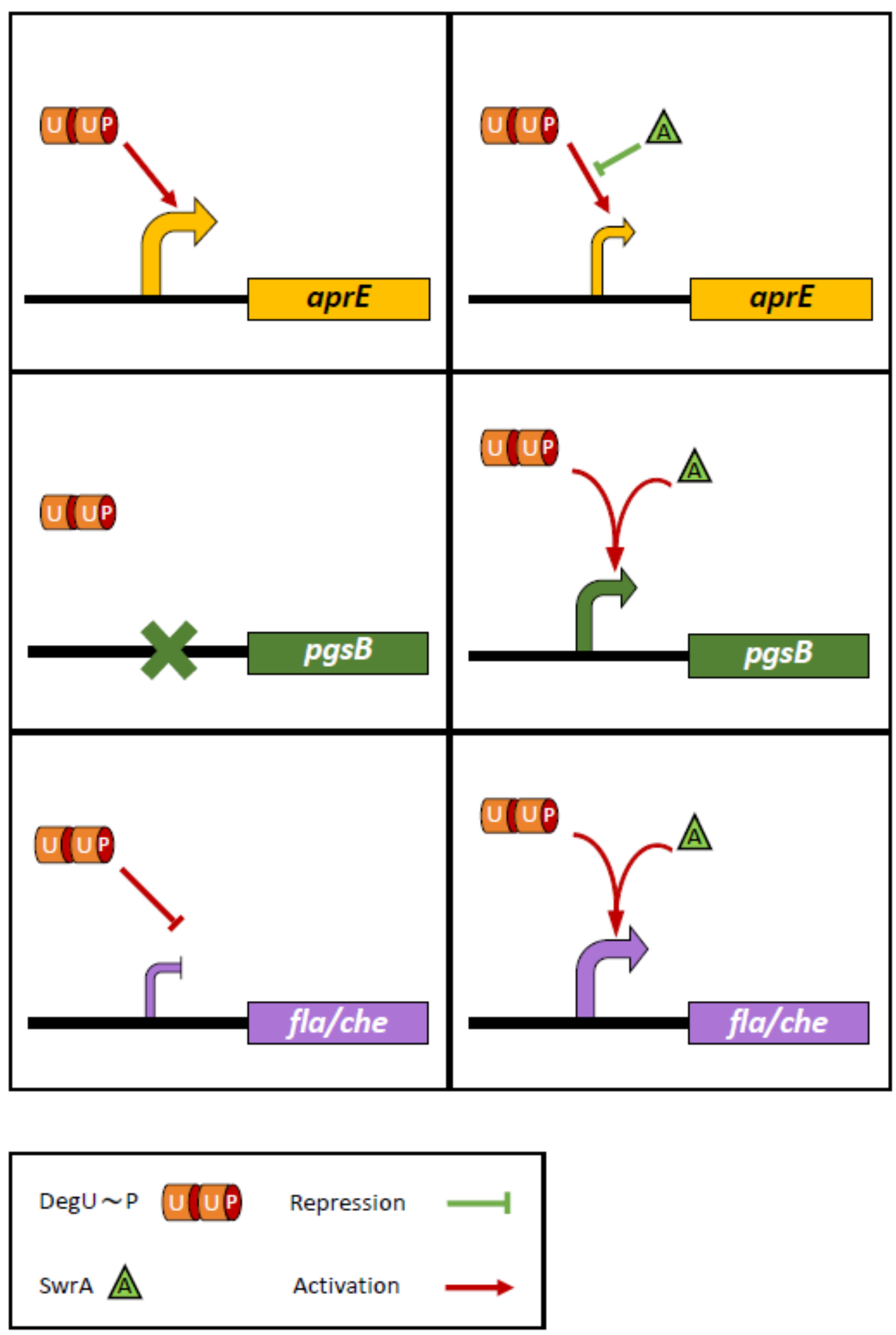


\section{DegS/Uwt}
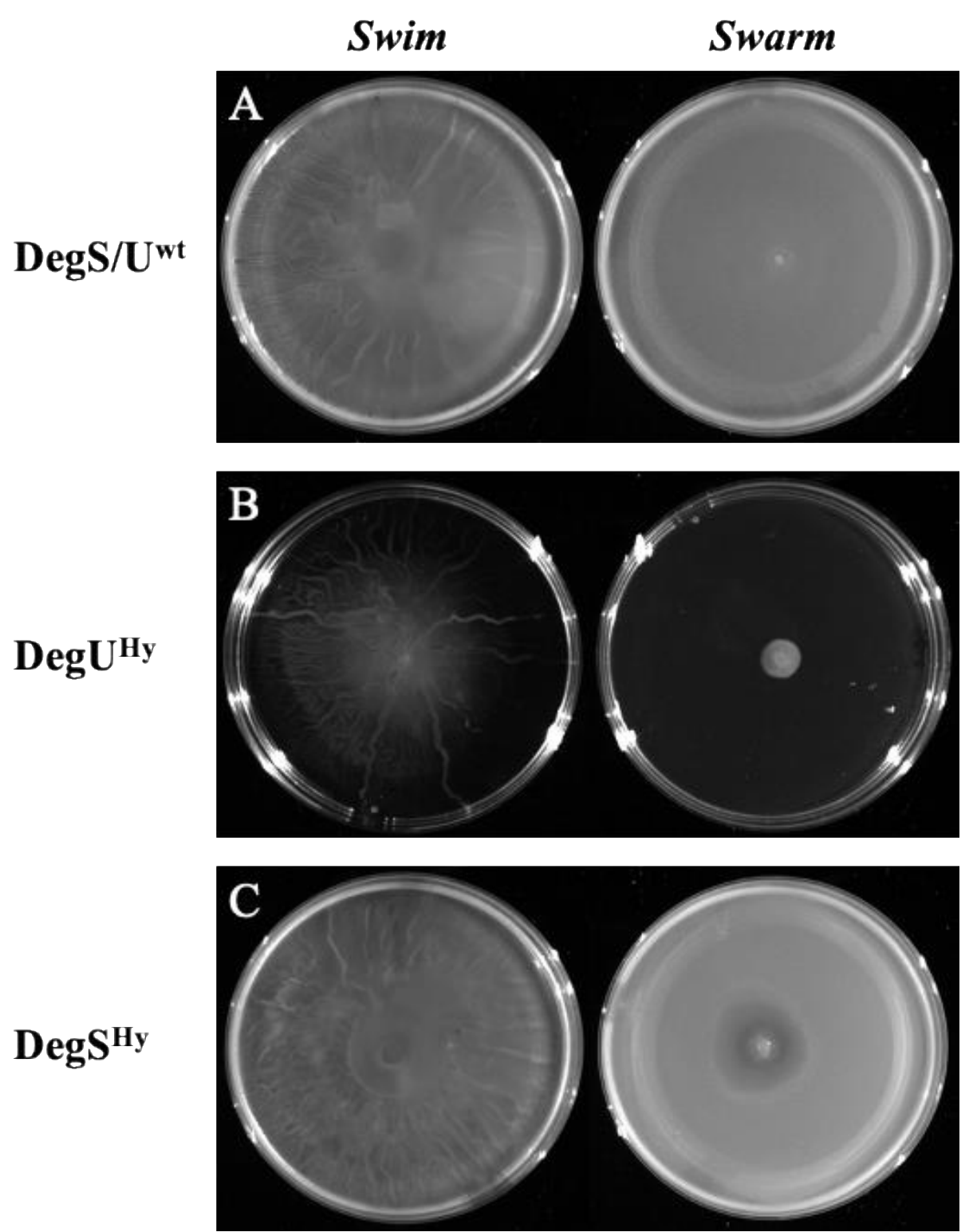
bioRxiv preprint doi: https://doi.org/10.1101/2021.05.07.443137; this version posted May 8, 2021. The copyright holder for this preprint (which was not certified by peer review) is the author/funder, who has granted bioRxiv a license to display the preprint in perpetuity. It is made available under aCC-BY 4.0 International license.

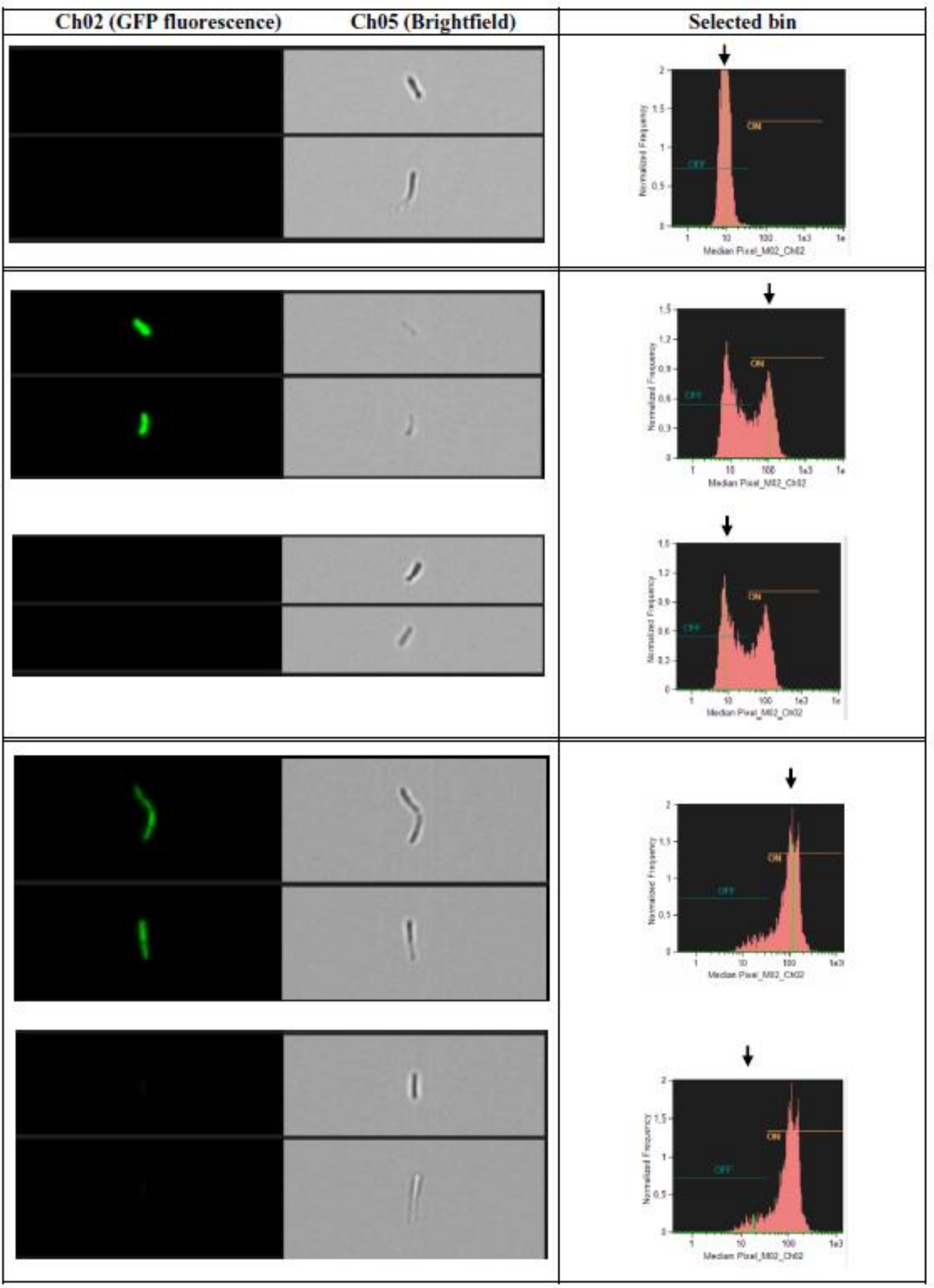

Fig. S2. Cell images collected during Flow Cytometry. Representative images of Papre-GFP containing cells collected from the different intensity bins which are pointed by an arrow on the graphs in the right panels. On the left, identical images as acquired in the fluorescence channel 501 (Ch02) and in the brightfield channel (Ch05). 